\title{
GENERATION AND DIFFERENTIATION OF GROUP II KIMBERLITES: CONSTRAINTS FROM HIGH PRESSURE EXPERIMENTS 10 GPA
}

\author{
Peter Ulmer ${ }^{1}$ and Russell Sweeney ${ }^{2}$ \\ ${ }^{1}$ ETH Zurich, Switzerland; ${ }^{2}$ De Beers Geoscience Centre, South Africa
}

\section{INTRODUCTION}

The primary goal of this study is to examine kimberlite origins by investigating its high-pressure phase equilibria to evaluate them in the context of other volatile-rich mantle samples, such as carbonatites and hydrous mantle xenoliths, which represent a spectrum of small-degree mantle melts or fluids (e.g. MARIDs, or mica-amphibole-rutile-ilmenite-diopside suite of mantle xenoliths; Dawson and Smith, 1977). Close association of K-rich micaceous group II kimberlites (orangeites) and MARIDs have been proposed on the bases of (1) regional distribution of MARIDs and group II kimberlites, restricted exclusively to the Kaapvaal Craton (Mitchell, 1995); (2) geochemistry (major, trace and isotope geochemistry reveal strong similarities between MARID-type xenoliths and micaceous, group II kimberlites, e.g. Jones, 1989); and (3) overlapping ages of group II kimberlites and MARIDs in the range 110 to 150 my (Konzett et al., 1998). We present experimental phase equilibria data on an average group II kimberlite to constrain its generation from metasomatized peridotitic mantle and to evaluate its differentiation products at mantle conditions.

\section{EXPERIMENTAL SETUP}

The selected starting composition (Table 1, labeled A) corresponds closely to the average group II kimberlite composition reported by Smith et al. (1985) (GPII, Table 1), except for a higher $\mathrm{Na}_{2} \mathrm{O}$ content ( 0.93 instead of 0.10 wt.\%) to explore $\mathrm{Na}-\mathrm{K}$ relationships and a higher $\mathrm{CO}_{2}$ and lower $\mathrm{H}_{2} \mathrm{O}$ content resulting in about twice the $\mathrm{x}_{\mathrm{CO} 2}(0.37$ instead of 0.18$)$ compared to the group II kimberlite reported by Smith et al. (1985). For comparison, the starting compositions of the experimental studies by Sweeney et al. (1993) on a MARID xenolith (MARID) and on a group II kimberlite by Yamashita et al. (1995) (YAM) are also given in Table 1.

The starting composition of the group II kimberlite listed in Table 1 (A) was synthesized from reagentgrade chemicals. Fe was added as pre-synthesized fayalite, and carbonate as $\mathrm{CaCO}_{3}, \mathrm{~K}_{2} \mathrm{CO}_{3}, \mathrm{Na}_{2} \mathrm{CO}_{3}$, and $\mathrm{MgCO}_{3} . \mathrm{H}_{2} \mathrm{O}$ (5 wt.\%) was either added by microsyringe $( \pm 0.5 \mathrm{wt} \%$ accuracy, piston cylinder experiments) or as $\mathrm{Mg}(\mathrm{OH})_{2}$ (multi-anvil experiments). Initially, Pt and AgPd capsules (welded shut) were used. However, considerable Fe-loss was observed in a few high temperature runs. Subsequent runs were conducted with graphite liners contained in welded Ptcapsules.

Up to $3.5 \mathrm{GPa}$, end-loaded piston cylinders with $\mathrm{NaCl}$ pyrex assemblies were used. All experiments at pressures $>3.5 \mathrm{GPa}$ were performed in a cylindrically constrained multi-anvil apparatus using WC cubes with $12 \mathrm{~mm}$ truncation edge lengths and calibrated on the quartz/coesite, fayalite/[- $\mathrm{Fe}_{2} \mathrm{SiO}_{4}, \mathrm{CaGeO}_{3}$ (gar/per), and coesite/stishovite phase transitions.

Alkali- and carbonate-rich experimental charges pose a particular challenge for preparation and analysis: The $\mathrm{K}$-rich quenched liquid contains $\mathrm{H}_{2} \mathrm{O}$-soluble carbonates. All charges were embedded in epoxy resin and ground to expose the centre of the charge. Final polishing with diamond powder was performed under petrol to avoid dissolution of alkali-carbonates. Charges were analyzed with a Cameca SX50 electron microprobe.

\section{Table 1: Starting Materials, Average Group II Kimberlite and MARID}

\begin{tabular}{lllll} 
& A & GPII & MARID & YAM \\
\hline $\mathrm{SiO}_{2}$ & 35.48 & 36.30 & 49.94 & 39.10 \\
$\mathrm{TiO}_{2}$ & 1.00 & 1.00 & 3.13 & 1.02 \\
$\mathrm{Al}_{2} \mathrm{O}_{3}$ & 3.16 & 3.20 & 6.78 & 3.05 \\
$\mathrm{Cr}_{2} \mathrm{O}_{3}$ & 0.30 & n.d. & 0.16 & n.d. \\
$\mathrm{FeO}$ & 8.22 & 7.60 & 6.98 & 8.38 \\
$\mathrm{MnO}$ & 0.24 & 0.20 & 0.07 & n.d. \\
$\mathrm{MgO}$ & 29.10 & 29.70 & 21.72 & 30.20 \\
$\mathrm{NiO}$ & 0.44 & n.d. & 0.11 & n.d. \\
$\mathrm{CaO}$ & 5.88 & 6.00 & 5.91 & 6.18 \\
$\mathrm{Na} \mathrm{N}_{2} \mathrm{O}$ & 0.93 & 0.10 & 0.99 & 0.17 \\
$\mathrm{~K}_{2} \mathrm{O}$ & 3.17 & 3.20 & 7.21 & 3.55 \\
$\mathrm{CO}_{2}$ & 7.14 & 3.60 & 0.00 & 4.37 \\
$\mathrm{H}_{2} \mathrm{O}$ & 4.97 & 6.80 & 0.00 & 3.31 \\
Total & 100.03 & 98.80 & 100.00 & 99.33 \\
\hline
\end{tabular}

Abbrev.: A: Starting material of this study; GPII AVE: Average group II kimberlite (Smith et al., 1985); MARID: starting material of Sweeney et al. (1993); GPII YAM: starting material of Yamashita et al. (1995). 


\section{RESULTS}

The results of quenching experiments are presented on Figure 1. The most prominent feature of the phase diagram is that the group II kimberlite composition is multiply saturated with olivine-orthopyroxene-garnet (garnet-harzburgite mineralogy) over a wide $\mathrm{P}-\mathrm{T}$ range. The liquidus was not encountered; even at $1480^{\circ} \mathrm{C}$ and $6 \mathrm{GPa}$ or $1600^{\circ} \mathrm{C}$ and $9.5 \mathrm{GPa}$. Phlogopite has a limited stability field, confined to low pressures and temperatures $\left(\leq 4.5 \mathrm{GPa}\right.$ and $\left.1250^{\circ} \mathrm{C}\right)$ much less than its maximum thermal and pressure stability of 9 to $10 \mathrm{GPa}$ and $1400^{\circ} \mathrm{C}$ in simple systems. No other K-bearing silicate phase was found to be stable outside the restricted phlogopite stability field, even at the highest pressures and lowest temperatures (e.g. $900^{\circ} \mathrm{C}, 8 \mathrm{GPa}$ ) all $\mathrm{K}$ was contained in a $\mathrm{CO}_{2}$-rich alkali-carbonatite melt. Similar phase relations limiting the occurrence of phlogopite have been observed by Sweeney (1994) in $\mathrm{Na}-$ and K-rich carbonatites, respectively.

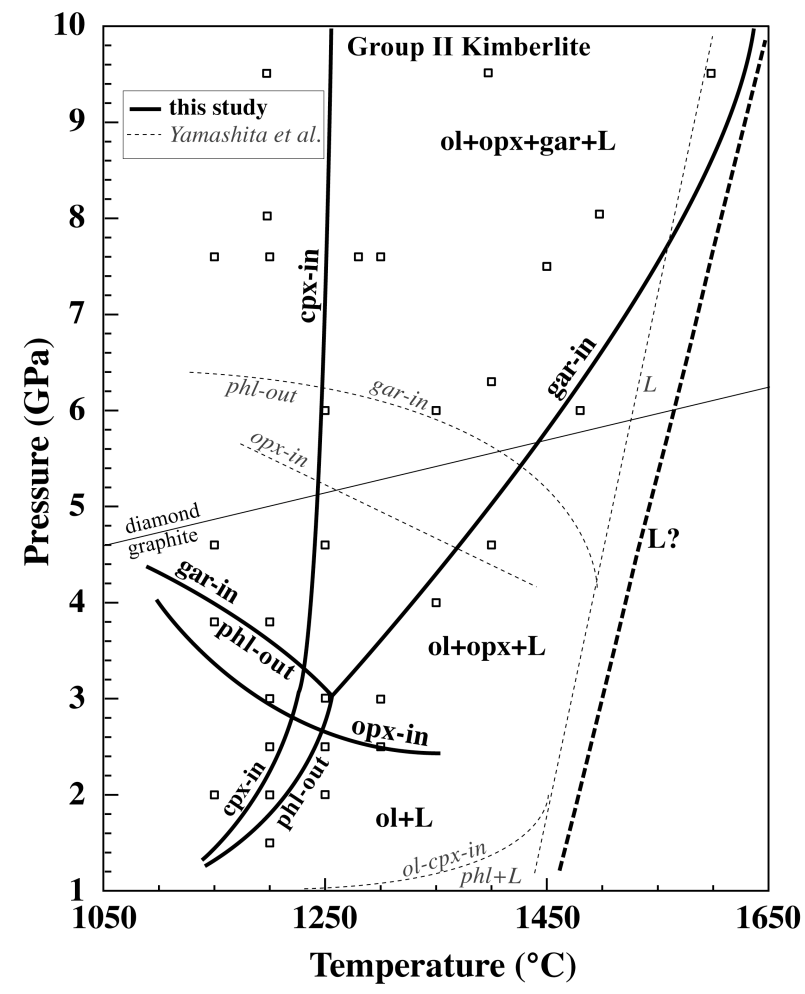

Figure 1: Pressure-temperature diagram showing the phase relations of group II kimberlite experiments. Small open squares indicate single experiments performed on composition A (Table 1). Solid lines and bold labeled phases indicate the results of this study; dashed lines and phases labeled in italics denote the results of Yamashita et al. (1995) that are given for reference and are discussed in the text.
Multiple saturation of the group II composition in lherzolitic phases occurs around $3 \mathrm{GPa}$ and $1250^{\circ} \mathrm{C}$, but at much lower temperatures than the liquidus for this composition. In addition, the composition of these multiply saturated liquids are significantly modified from a group II composition by olivine and orthopyroxene crystallization producing carbonatitic compositions that bear little resemblance to a kimberlitic melt segregated at higher pressure. In general, multiple saturation with olivine + opx + garnet $\pm \operatorname{cpx}$ near the liquidus is regarded as prime requirement for a primary magma to be in equilibrium with a mantle residue. A kimberlitic primary melt may additionally be saturated with a K-phase (phlogopite or $\mathrm{K}$-richterite) and a $\mathrm{CO}_{2}$-rich fluid or carbonate phase (mineral or melt). However, the concept of multiple saturation with mantle source constituents is only valid if no reaction relations between original source mineralogy and the product (incipient) melt occurs. In the case of $\mathrm{CO}_{2}$-rich kimberlitic magma, this is unlikely: Phlogopite and/or K-richterite exhibit incongruent melting on their own compositions producing a K-rich melt/fluid and garnet-opx-olivinebearing residues even in the absence of $\mathrm{CO}_{2}$. Therefore, the absence of a K-rich phase close to the liquidus is not a proof of its absence in the mantle protolith, but it might have reacted out at near-solidus conditions. From the experiments, we infer the following reactions that destabilizes phlogopite at 3 to $4 \mathrm{GPa}: 2$ phlogopite + $\mathrm{CO}_{2}=3$ opx + garnet $+\mathrm{K}_{2} \mathrm{CO}_{3}$ (liquid) $+\mathrm{H}_{2} \mathrm{O}$ (liquid) or in the presence of carbonate instead of $\mathrm{CO}_{2}$-fluid: 2 phlogopite $+\mathrm{MgCO}_{3}=2$ opx + olivine + garnet + $\mathrm{K}_{2} \mathrm{CO}_{3}$ (liquid) $+2 \mathrm{H}_{2} \mathrm{O}$ (liquid).

The exceedingly high liquidus temperature of the group II kimberlite composition $\left(>1500^{\circ} \mathrm{C}\right.$ at $6 \mathrm{GPa}$ and $>$ $1600^{\circ} \mathrm{C}$ at $\left.9.5 \mathrm{GPa}\right)$ might indicate that kimberlite compositions, determined from bulk chemical analyses of kimberlites, do not represent primary compositions, but are enriched in olivine, orthopyroxene and/or garnet, resulting from incorporation of dismembered harzburgitic upper mantle xenoliths forming part of the macrocryst assemblage characteristic for all but the most differentiated aphanitic kimberlites. If this interpretation is correct, the primary liquid would be less $\mathrm{MgO}$ - (and probably also less $\mathrm{SiO}_{2}-$ ) rich than the inferred compositions. The adjusted $\left(\mathrm{Na}_{2} \mathrm{CO}_{3}\right.$ added $)$ average group II composition of Smith et al. (1985), chosen for the present experiments, probably includes an overestimated amount of olivine/opx. Alternatively, if mantle xenolith incorporation has not been significant, group II kimberlite compositions represent liquid compositions, and it is most likely that such a liquid is in equilibrium with garnet harzburgite residue (garnet is required from trace element considerations). 
The potassium would derive from phlogopite or Krichterite introduced into the source assemblage by earlier metasomatism. The requirement of garnet as a residual phase constraints the group II kimberlite generation depth to pressures $>6 \mathrm{GPa}$ where garnet stability approaches the liquidus and is consistent with occurrence of diamond in group II kimberlites.

The presence of olivine as the most common phenocryst in kimberlitic magmas is in accordance with the phase relations at elevated temperatures for pressures $<2.5 \mathrm{GPa}$ (Fig. 1). The reaction of garnet + opx $+\mathrm{K}_{2} \mathrm{CO}_{3}+\mathrm{H}_{2} \mathrm{O}$ to phlogopite $+\mathrm{CO}_{2}$ at low temperatures and pressures is consistent with observations of preferential assimilation of opx and garnet by host kimberlite magma. Runs below $2.5 \mathrm{GPa}$ and temperatures $\leq 1200^{\circ} \mathrm{C}$ exhibit a paragenesis of olivine + phlogopite $+\mathrm{cpx}$ in a fine-grained matrix of quench phlogopite, calcite, olivine $\pm \mathrm{cpx}$. This assemblage corresponds to the typical phenocryst /microphenocryst association observed in macrocrystal group II kimberlites (orangeites). Monticellite, which is a typical groundmass phase in group I (basaltic) kimberlites is absent in the present experiments and is most probably related to the distinctly higher abundances of $\mathrm{K}$ and $\mathrm{Si}$ in group II kimberlites compared to group I kimberlites.

\section{Discussion}

The following discussion focuses on the results of the present experimental study and compares it with a similar study performed by Yamashita et al. (1995) on two different group II kimberlites from Makganyene Mine, South Africa. In Fig. 1 their results for the more primitive, macrocrystic group II kimberlite are reproduced. Their composition is comparable to the average group II composition we have chosen, except for lower volatile contents (Table 1). Yamashita et al. (1995) phase relations are generally similar to the ones obtained in the present study, with the exception that phlogopite has a much larger stability field, representing the only liquidus phase at pressures up to 2 GPa joined by olivine and clinopyroxene at higher pressures. Phlogopite disappears at high pressures (4 to $6 \mathrm{GPa}$ ) in a similar fashion as observed in our experiments through a reaction forming garnet and orthopyroxene. The $\mathrm{x}_{\mathrm{CO} 2}$ is nearly identical in the two studies (0.351 and 0.370) and should not cause this discrepancy in phlogopite stability. Comparing the stability of phlogopite in pure end-member systems reveals that the stability field inferred by Yamashita et al. (1995) exceeds the experimentally determined stability limits of phlogopite-opx or phlogopite-cpx by 150 to $300^{\circ} \mathrm{C}(1-6 \mathrm{GPa})$. Even pure end-member $\mathrm{OH}-$ phlogopite has a considerably lower thermal stability at 1 to $3 \mathrm{GPa}$ than inferred by Yamashita et al. (1995). The only explanation we can come forward to explain the exceedingly high phlogopite stability in the experiments of Yamashita et al. (1995) is the presence of considerable amounts of Fluorine in their starting material (not reported) that is known to stabilize phlogopite to much higher temperatures. Our experiments were Fluorine-free. The thermal stability of phlogopite in our experiments matches well the experimental data from Modreski and Boettcher (1972) and Luth (1997) on phlogopite-opx and phlogopite-cpx in the range 1250 to $1300^{\circ} \mathrm{C}$ at $3 \mathrm{GPa}$. Little is known about the Fluorine content of group II kimberlites; Mitchell (1995) reports generally low F-contents of phlogopite micas in group II kimberlites ( $\leq 1 \mathrm{wt} . \%)$, mostly in the range 0.1 to $0.6 \mathrm{wt} . \%$.

The experiments of Yamashita et al. (1995) would allow formation of group II kimberlites at $\approx 4.5 \mathrm{GPa}$ from a phlogopite-garnet peridotite. However, the presence of diamonds in most group II kimberlites and pressure estimates from garnet-bearing mantle xenoliths entrained in group II kimberlites indicate pressures in excess of $6 \mathrm{GPa}$, which argues against such a low pressure of magma generation. In addition, both studies (and so far all multiple saturation experiments on 'primary kimberlites') failed to stabilize a carbonate phase in the range of liquidus temperatures and therefore require that kimberlites are not formed at the carbonated peridotite solidus but at some temperature above where carbonate phases have been consumed. Alternatively, a two-stage process for the formation of carbonate-rich primary magmas from peridotitic sources in the stability region of diamond is required.

The mutual exclusion of K-bearing (hydrous) silicates and carbonates/carbonatites in the stability field of diamonds points towards a multistage origin for group II kimberlites. Several scenarios fulfilling the minimum requirements can be envisaged:

First, phlogopite or K-richterite bearing peridotites, e.g. above a subducting slab or in cold regions of a subcratonic lithosphere, are invaded by $\mathrm{CO}_{2}$-rich fluids or near-solidus carbonatitic melts. This infiltration leads to the immediate breakdown of the K-silicate-hydrate and to the formation of a group II kimberlitic magma in equilibrium with a garnet-harzburgite residue.

Second, a carbonated (dolomite or magnesite bearing) peridotite is infiltrated by potassic hydrous fluids originating, for example, from the breakdown of phengitic white mica or phlogopite in subducted oceanic lithosphere (Schmidt, 1996; Stalder et al., 2002). The presence of K-rich hydrous fluid or melt (probably supercritical at $6 \mathrm{GPa}$, Stalder et al., 2002) destabilizes the carbonate phase by dramatically 
lowering the solidus temperature of the peridotite and leads again to the formation of group II kimberlite. For both processes, the destruction of phlogopite and generation of K-rich carbonatitic liquid will occur at pressures $>3 \mathrm{GPa}$ because olivine $+\mathrm{CO}_{2}$ are stable at lower pressures, and also phlogopite is stable at these conditions in equilibrium with a carbonate-rich melt (Sweeney, 1994) or $\mathrm{CO}_{2}$ (Wyllie, 1978; Wendlandt and Eggler, 1980). Both processes require a first metasomatism event that either leads to the formation of a K-silicate-hydrate or a carbonate-bearing peridotite. The second stage infiltration of either a carbonatite liquid or a K-rich hydrous fluid results in the production of a K-rich kimberlitic liquid. Group II kimberlites, therefore, can only be produced in cold lithospheric mantle that suffered multiple metasomatism events.

The present experiments failed to establish a direct link between the K-rich kimberlites (group II / orangeites) and the K-rich MARID xenoliths despite the observation that both occur contemporaneously within a limited space and narrow time interval, and share common isotopic signatures (lithospheric provenance). The present experiments never stabilized K-richterite, and ilmenite and rutile were only observed in a few low-temperature experiments at pressures exceeding 6 GPa. However, the common link might be provided by the requirement of the proposed K-rich hydrous fluid/melt. Recent experimental studies by Stalder et al. (2002) and Kessel et al. (2003) constrained the compositions of hydrous fluids/melts in equilibrium with a phlogopite and eclogite residue at pressures of 6 $\mathrm{GPa}$ and temperatures ranging from $800-1200^{\circ} \mathrm{C}$. The measured fluid compositions are strongly peralkaline leaving a garnet-dominated residue. Such fluids, either originating from subducted, hydrothermally altered oceanic lithosphere or from metasomatically altered lithospheric peridotites and eclogites, might be responsible for both the generation of group II kimberlites by interaction with carbonate or diamondbearing peridotites (in the lowermost part of the subcratonic lithosphere) as well as for the formation of MARIDs by crystallization and reaction with common lithospheric garnet-harzburgite or lherzolite. Similar fluids might also represent the metasomatic agents responsible for the formation of phlogopite- (PP) and phlogopite-K-richterite-peridotites (PKP) observed as mantle xenoliths in kimberlites from the Kaapvaal Craton.

\section{REFERENCES}

Dawson, J.B., Smith, J.V., 1977. The MARID (mica amphibole - rutile - ilmenite - diopside) suite of xenolith in kimberlites. Geochim. Cosmochim. Acta 41, 309-323.

Jones, A.P., 1989. Upper mantle enrichment by kimberlitic or carbonatitic magmatism. In: Bell, K. (Ed.) Carbonatites, Genesis and Evolution. Unwin Hyman, pp. 448-463.

Kessel, R., Ulmer, P., Pettke, T., Schmidt, M.W., Thompson, A.B., 2003. Experimental determination of highpressure fluid composition in equilibrium with residual eclogite. J. Conf. Abs. (in press).

Konzett, J., Armstrong, R.A., Sweeney, R.J., 1998. The timing of MARID metasomatism in the Kaapvaal mantle: An ion probe study of zircons from MARID xenoliths. Earth Planet. Sci. Lett. 160, 133-145.

Luth, R.W., 1997. Experimental study of the system phlogopite-diopside from 3.5to $17 \mathrm{GPa}$. Am. Mineral. 82, 1198-1209.

Mitchell, R.H., 1995. Kimberlites, Orangeites, and related rocks. Plenum Press.

Modreski, P.J., Boettcher, A.L., 1972. The stability of phlogopite + enstatite at high pressures: A model for micas in the interior of the earth. Am. J. Sci. 272, 852869.

Schmidt, M.W., 1996. Experimental constraints on recycling of potassium from subducted oceanic crust. Science 272, 1927-1930.

Smith, C.B., Gurney, J.J., Barton, E.S., Bristow, J.W., 1985. Geochemical character of southern African kimberlites: a new approach based on isotopic constraints. Trans. Geol. Soc. S. Africa 88, 267-280.

Stalder, R., Ulmer, P., Günther, D., 2002. Fluids in the system forsterite-phlogopite- $\mathrm{H}_{2} \mathrm{O}$ at 60 kbar. Schweiz. Mineral. Petrogr. Mitt. 82, 15-24.

Sweeney, R.J., Thompson, A.B., Ulmer, P., 1993. Phase relations of natural MARID composition and implications for MARID genesis, lithospheric melting and mantle metasomatism. Contrib. Mineral. Petrol. $115,225-241$.

Sweeney, R.J., 1994. Carbonatite melt compositions in the earth's mantle. Earth Planet. Sci. Lett. 128, 259-270.

Wendlandt, R.F., Eggler, D.H., 1980. The origin of potassic magmas: 2. Stability if phlogopite in natural spinel lherzolite and in the system $\mathrm{KAlSiO}_{4}-\mathrm{MgO}-\mathrm{SiO}_{2}$ $\mathrm{H}_{2} \mathrm{O}-\mathrm{CO}_{2}$ at high pressures and high temperatures. Am. J. Sci. 280, 421-458.

Wyllie, P.J., 1980. The origin of kimberlite. J. Geophys. Res. 85, 6902-6910

Yamashita, H., Arima, M., Ohtani, E., 1995. High pressure melting experiments on Group II kimberlite up to 8 $\mathrm{GPa}$; implications for mantle metasomatism. Sixth Int. Kimberlite Conf.; extended abstracts, pp. 669-671.

Contact: P Ulmer, Department of Earth Sciences, ETH-

Zentrum, Sonneggstr. 5, CH-8092 Zurich, Switzerland, Email: peter.ulmer@erdw.ethz.ch 